\title{
Introductory lecture: Pollen food allergy syndrome
}

\author{
Riccardo Asero \\ From Food Allergy and Anaphylaxis Meeting 2011 \\ Venice, Italy. 17-19 February 2011
}

The term pollen-food allergy syndrome (PFAS) defines a series of clinical symptoms appearing shortly after the ingestion of plant-derived foods in subjects with pollen allergy. The patients with PFAS are primarily allergic to pollen and subsequently react to food allergens as a consequence of the homology between pollen and plantfood proteins. The two highly conserved proteins responsible for the large majority of cases of pollen-food allergy syndrome are the pathogenesis-related proteins group 10 (PR-10), including the major birch pollen allergen Bet $\mathrm{v} 1$ and homologous proteins in different fruits and vegetables, and profilin, a plant pan-allergen present in cell structure of all the vegetable kingdom. Although it has been generally thought that the clinical expression of the pollen food-allergy syndrome is uniquely the socalled "oral allergy syndrome", recent reports suggest that the ingestion of particular foods may be associated with systemic symptoms as well. Recombinant PR-10 proteins and recombinant profilins from different sources are presently available for diagnostic purposes. The presentation will review the available data about the clinical expression, diagnosis, and therapy of the pollenfood allergy syndrome.

Submit your next manuscript to BioMed Central and take full advantage of:

- Convenient online submission

- Thorough peer review

- No space constraints or color figure charges

- Immediate publication on acceptance

- Inclusion in PubMed, CAS, Scopus and Google Scholar

- Research which is freely available for redistribution

\section{Biomed Central}

